\title{
POLITICAL REFLECTION AND FORMATION OF A NEW INSTITUTIONAL ENVIRONMENT
}

\author{
Saša Trandafilović and Nebojša Dragović** \\ Republic of Serbia, Ministry of Defence, \\ Budget and Finance Sector, Department of Budget
}

Dealing with complex economic, social and political challenges of our time requires the most competent people. The process of identifying political parties with their top leaders is not a phenomenon inherent in our political situation, but a widely accepted concept of concentration of power and strengthening the leadership influence in all societies. The overall objective of the paper is to point to the importance of implementation of reform commitments in terms of sustainable development of the Republic of Serbia based on practical and theoretical experiences, as well as a critical examination of the institutional behaviour of the current political elite in shaping the institutional environment, implementing reform commitments and eliminating political dichotomy in passive behaviour of one part of the institutional decision-makers in accordance with the efforts and activities of the current Prime Minister to protect national and strategic interests of the Republic of Serbia. Thus, some of the key factors for success of reforms will be analysed in this paper, as well as the type of correlation of reflection of political decisions with sustainable economic development and equitable social distribution.

Key words: new institutional environment, democratic nihilism, structural authoritarianism, current political environment

JEL Classification: P21 P27

\section{Introduction}

M/e study history in order to learn "how" to survive, "what" to do to have a better tomorrow and finally, to believe or doubt the capability of "friends" from 11 Nemanjina Street. Previous behaviour of political decision-makers and their competences expressed through the exercise of delegated responsibilities in the dominant institutions of the system has only confirmed the reason our country stands at the bottom of the European economic ladder. Another proof is that politicians have often made wrong choices.

\footnotetext{
*Col PhD Saša Trandafilović, e-mail: sasa.trandafilovic@mod.gov.rs

${ }^{*}$ PhD Nebojša Dragović, e-mail: nebojsa.dragovic@mod.gov.rs
} 
The higher the skills, professional experience and responsibility in carrying out entrusted functions, the more likely it is that one will establish a harmonious and mutually positive relationship between political elite and the society on a long term basis.

Control of system institutions is a key existential foothold of all authorities in modern societies, and only within and through the influence on the system institutions can the political power be constant and strong (Sarajlic, 2009: 29).

\section{Democratic Nihilism}

Experience has shown that it is easy to carry out political changes, but very difficult to carry out economic and social reforms, where the main problem is not the severity of the reforms, but their equity and social solidarity. When "October the $5^{\text {th" }}$ is analysed through activities of distribution of income, it is revealed to have been a giant instrument of redistribution (Arandarenko, 2012), which was the high price paid by the vast majority of citizens of the Republic of Serbia.

After the October changes on the political scene entered a new political constellation, as a set of incomparable elements (a mixture of unscrupulous leaders of "bus" parties, short-sighted obsessives and corrupt complexes), which underestimating everything "old" started building an anarchic institutional environment where everything was possible and permitted for the chosen ones. Quite contrary to the explicated, the institutional behaviour very quickly produced disastrous economic and social effects of promises they had made. Instead of building a political existence in favour of the interests of society, it put the assigned mandate in function of its own interests, with "instinctive" sense that the national wealth, regardless of human, national or social character, was its personal property. In such an environment, the manipulation of the masses and their ultimate humiliation was a key instrument which the democratic government used to build the political and material existence. Getting rich irrationally and enormously, without moral discipline clearly indicates that publicly proclaimed principles of acting and living within the framework of genuine social values were completely eliminated in the practice. In such exploitative and extremely degrading treatment, criminalization of politics, or direct collusion of politics with crime affected almost all segments of society. Slogans, promises, domination of politics over the economy, reproduction of crisis, apologetics and palliative reforms were taken from the "old" times (Draskovic V., Draskovic M.:2012).

Illusory "economic and social polarization" that concentrated the power to dispose of the whole social capital and all available resources of the Republic of Serbia within the privileged circle of individuals, is yet incompatible with the "immortal" remaining in power. Nothing is more dangerous for a country than to demolish an entire floor where honour, reason and virtue live, or to leave just two extremes: those who barely make ends meet and those who have "unusual" wealth (Robert, 1938: 213). That was confirmed in 2012 election.

A lot of bad things have been said about democratic government, not for revenge of former oppositionists but because of the devastating economic and social outcomes. It is therefore unclear why the current government is still losing "precious time" proving who is 
Political Reflection and Formation of a New Institutional Environment

to blame for the disastrous situation that was left as a legacy, unless it is its way of hiding its own failures. After all, nationally responsible and politically coherent parties seek their social justification in decadence of economic and social policies they lead, as an open and public debate, with alternate solutions (regardless of who proposed them) and acceptance of social most suitable solutions.

A perennial crisis in building the new system of the Republic of Serbia by the previous establishment clearly indicates that not only the occasional external causes were the issue, but basically deep socio-economic contradictions caused by the neoliberal macroeconomic policy. The transformation of the state and social property did not allow a more rational and efficient use of resources, but it deprived society of that property. And when the system is not keeping pace with strategic national interests in its development, the ruling establishment is increasingly faced with the issue of social tolerance and civic trust. Probably because the "despotism of the ruling minority" is reflected in the fact that this "intelligent and therefore privileged minority" rules "as if it understands the real interests of the people better than they do themselves" and that "it does not represent the people any more but itself and its pretensions to govern the people" (Bahro, 1977: 34).

\section{Political and Economic Mantra}

In the distant 60-ies economists have concluded that it was impossible to identify the economic and political as two separate worlds. In the domain of the system of executive institutions the mutual relationship was even more obvious, with "consciously" established national agency with selected personnel who were supposed to monitor economic trends publicly displayed as "an extension of government competence" and not "as the rise of" economic and entrepreneurial sponsors to the level of political eminence.

At the beginning of "Milosevic's" reign, "clairvoyant" directors of state and sociallyowned enterprises and entrepreneurs with financial and other support joined his political leadership and ideology of that time. Those who hesitated used their chance for survival in the second round by joining the party of the president's wife. After the fall of their regime, they continued further domination mainly owing to professional, moral and intellectual degradation of so-called democratic politicians and bringing the system institutions and institutional power and influence under the level they deserve.

Collusion of institutionally privileged tycoons with political authorities that had lasted for decades could not be terminated overnight. It is easy to arrest "temporarily" and let notorious businessmen out on bail or with an electronic tag, but it is much harder to build independent and efficient judicial institutions of the system and make their representatives incorruptible.

At present, authoritative element of the Prime Minister dominates institutionally in two ways: as a personal element which is engaged in the resolution of all issues, even those that are not within the scope of the jurisdiction of the Prime Minister, as well as a party element that creates its ideology. On the other hand, according to the simple Marxist point of view, a big businessman is actually the real holder of power and influence. 


\section{Structural Authoritarianism}

The current Serbian Prime Minister is not an "aristocratic" product, based on the nobility of hereditary origin. He does not have his compact bases in a small circle of famous "ruling" families, whose members would be able, potentially and actually, to take up positions of the highest social circles which coincide with each other and to provide him with "unconditional" support.

The dominant influence of the Prime Minister is more than obvious on the current political scene.

Strengthening the authoritative role of individuals is the result of forcing the disintegration process in the former state that lasted for decades, along with the international support. In such circumstances, when the composition of the state leadership adapted to republican interests, the national leader institute came to the fore. The dazzling leader's success at the republic level was mostly influenced by a formal institutionalism through "blockade" of functioning of the legitimate institutions of the system, with the personnel mechanism completely subordinate to the interests of the republic. Such an institutional vacuum leads to affirmation and creates leaders who actually have never had a mediocre political capacity, and much less statesmanship. That way, previously completely unknown people became even Heads of State, which on the other hand was no accident.

There is no doubt that the current Prime Minister attracts wide national and international attention, more thanks to the personal authority than to restrictive reform measures that find less understanding in most European countries. Presented, but not yet realized, economic and social results are so far still at the stage of wishful thinking; regardless of the conviction of the Prime Minister that these results will soon manifest themselves in the best light possible. On the other hand, the system is not just comprised of the Prime Minister and his team, but also of the "executive" owners of the private capital and entrepreneurs who have accumulated their wealth thanks to the previous institutional support. Accordingly, the current environment implies artificial stability or instable collusion of political and economic elements.

There is a kind of mutual attraction between people who have subordinated their individual abilities, creativity and knowledge to social or national interests. Although these people are few, it is essential that they exist, operate, offer a real example and a choice of socially equitable solutions and finally, invite all others to join them on this path. Current Prime Minister has chosen this path, and what about most of the others?

Multi-year decline in gross domestic product affected the exceptionally difficult economic and social situation in the country. High unemployment rate, structural imbalance of the economy, internal and external deficit, and the expected but unrealized foreign investments, protests and more potential "surprises" present challenges that will be "more" a job for the Prime Minister and "less" for the government to deal with intensively in the coming period. 


\section{The Current Political Environment}

Every political power, regardless of its stated objectives, performs the entrusted function through the institute of "strong" state interventionism. The cleaned coast of the Sava is not a subject of international public tender, but of the predetermined purpose and Arab partners that agreed with it in advance. But that was also the case with FIAT and many other companies, with the support of SIEPA. The only "honest" difference between the former and current endeavours is in adopting Lex specialis, for public verification of the already agreed project.

Formation and operation of the current government exist in a formal institutional form that is essentially subordinate to the limited impact of the "independent politicians" and the growing influence of "executive politicians" in the function of protecting its political leader from all those who disagree with what he says or "believes". Party and any other form of poltroonery seems more lucrative business than respecting professional expertise, skills, personal existence, moral values and courage to tell the truth to a leader and suggest the correct solutions.

Undisputedly, the ruling elite is made of a small number of prominent people who work in the fields of politics, economy, military, police and other authorities, but that part is practically negligible. The reason is simple: most duties of responsibility are entrusted to incompetent and uneducated persons to blindly advocate and support the party and leadership viewpoints, often not even realizing their basic meaning, regardless of their positive or negative content. The opposite behaviour would mean the end of their national political career. Therefore, the civil servants, who are loyal to the system and strategic national interests, are the biggest social and individual losers of the "institutional vacuum" governed by party authorities and wealthy tycoons, mostly thanks to the identification of their common interests.

The similarity of the members of the political elite in Western countries is reflected in the fact that most of them have gained the same or similar degree in education. Those are generally people with a university degree from Harvard, Princeton, Yale and other prestigious universities. In our conditions, among those who make the most important decisions, we find people who were not elected or appointed for those positions according to professional competence and relevant experience.

Not only institutional mechanisms that gave the power to the members of the ruling elite and the degree in education they had and where they were educated are important for their psychological, moral, value, and social affinities. The key factor of a "correct" choice is the criteria used for selecting, rewarding and promoting them. If these elements are respected in all functions and at all levels (with no exceptions), the elected officials become similar to each other. It is a basic precondition to create a "winning team" and remain in power. Slowly, shyly and timidly, nevertheless, the tendencies which lead to the establishment through the necessary objective criteria are observed and expressed.

Building modern economic and social environment can be affirmed only through the existence and functioning of developed and independent institutions of the system through which the projected social tasks and detected problems will be successfully solved. Similarly, the creation of team work requires making and adopting the most 
important decisions to be based on professional knowledge and experience. After all, if you take into account everything that man could be, solutions that he offers as an individual cannot and must not be "taken at face value". There must be a mechanism that checks the share of each participant in the creation and adoption of decisions and thus determines his purpose and reliability. Only then is the final decision made (Galbraith, 1973: 245).

In this situation, political "geniuses" and "know-alls" become unnecessary, and performances resulting from this (through team work and professional decision-making) become socially more useful. Coordination and approval of relevant people consist only of the fact that professional and competent people should be positioned and interconnected (as a team) in a way that will give the best results.

The institutional environment for promoting the development of entrepreneurship and private companies is still not institutionally rounded. There is almost no economic or other branch that guarantees the payment of goods or developed institute of institutionally guaranteed collection of receivables. The relevant committees and public enterprises are still under the influence of political patronage and political recruitment. The salary system is still differentiated, even in the public, or the budget sector.

One of the key areas of significance for driving economic growth and development are structural and institutional reforms with an aim to improve public and private sectors in order to contribute to the achievement of equitable and sustainable development according to their complementary advantages. New theories of development suggest that economic growth depends on political factors and their capacity to define common goals. Consequently, given the political dimension of state capacity, it is necessary to bear in mind the institutional approach to development, i.e. political dimensions of institutions that support effective social and economic development and, therefore, need and interest of the society to develop capacities to build better institutions. In order to make a developing state efficient as well, it is necessary to take greater responsibility, to create greater autonomy in relation to the private elite and to construct more complex and more demanding forms of action. Accordingly, the developed institutional structure, and the efficient functioning of institutions represent one of the basic factors of economic growth and development. Bilateral interaction sets up between institutional quality and economic growth. On the one hand, effective institutions have a positive impact on economic growth by reducing the risk of uncertainty, reduce information asymmetry (which results in a reduction of transaction costs) and increase macroeconomic stability. On the other hand, weak economic growth usually stimulates the rent seeking compared to the national ruling elite (corruption, direct expropriation of investments, etc.), and consequently leads to institutional traps, as well as to the rise of cost of institutional transformation (Lekovic, 2013: 42).

Modern concept of economic development implies that reform and other necessary changes cannot be achieved by creating political objectives, issuing political directives and political marketing. Without building modern institutional infrastructure, it is impossible to realize more productive and dynamic economic growth and development. If there is a clear vision of strategic and other national interests and goals, the state is obliged to build institutions of the system that will enable achievement thereof. In addition to encouraging creativity, motivation, initiative, entrepreneurship, curiosity, efficient 
Political Reflection and Formation of a New Institutional Environment

corporate management and healthy competition, they prevent the institutionalization of privileges and processual forms of domination and totalitarianism, as they represent the direct opposite of unlimited political power (Drašković, 2003: 147). Besides, people want the solution to their existential problems, not political daily aspirins and Band-Aids in the form of "institutional cosmetics".

\section{Today, the Most Pressing Issue: Salaries and Pensions}

Politicians assure us that the only way out of the economic and social crisis is the maximum belt-tightening, while requesting from the rich to sympathize and share the fate of the rest of the people. We hoped that this concerning "the rich" will come true, but also feared learned by experience, that "inhabitants of the coastal region have long known that it is not true that a rising tide lifts all boats and that, when accompanied by storm, it throws only the weaker boats to shore" (Stiglitc, 2004: 91).

We have adopted a restrictive wage and pension policy as a necessary condition for stabilization of the economy and creation of new jobs. But this does not in any case mean that we have accepted a partial and discriminatory institutional inconsistency in restricting salaries and pensions of state or public sector. Why are the National Bank of Serbia, National Mortgage Insurance Corporation, many public companies and other state institutions so "meritorious" for the performance of government and public affairs that wages of their employees are several times above the average of the employees of state authorities? After all, if they are so professional and competent personnel and deserve multiple higher earnings than other civil servants, it is "extremely unclear" why they were not assigned to the Prime Minister and the Government in order to provide expert support and thus fully contribute to the realization and implementation of the initiated reforms. It is indeed high time to finish with anti-institutional farce and disgrace if there really is a will to introduce a "payment order" in the country.

Finally, the restrictions have never been popular because nobody likes to be told that he/she must lose a part of salary or pension. If it is done partially, it can cause just the opposite effect from the expected one.

\section{Conclusion}

There is no successful government that functions without defined a strategic orientation and a clear vision of long-term development, i.e. without expressed focuses, priorities and gradualism in the execution of institutional tasks, achievement of results, and achievement of set objectives for fulfilment (justification) of entrusted social mission. Whether further development will be faster or slower depends mostly on the creativity, skills and wisdom of decision-makers, as well as their attitude towards the strategic national priorities through appropriate institutional support for the sustainable growth and development of the Republic of Serbia.

Modern, flexible and efficient economic institutions are a basic condition for the development of economic freedom, entrepreneurship, democracy and market economic activity, stable economic relations and sustainable economic development. Their 
stability, development and independent personnel mechanism depend on the current Prime Minister and the Government. Besides, the Prime Minister contributed most to prosecution of untouchables. But even his demonstrated courage, unlike of many current officials, is not sufficient to complete what has been initiated without functioning of independent and effective institutions of the system.

Prime Minister's commitment to modern and developed Serbia and day and night efforts to overcome the economic and social crisis in the shortest period possible are on the verge of human endurance. Does that indicate something about the team that he has chosen?

The reforms are not only an institutional embodiment of the new system and the new code of conduct as a roadmap to a better economic and social future and the limits within which may and can be moved. In addition to the "new roadmap", "inherited" dangers and prejudices will continue to exist. In order to really change the system as a whole, first of all, it is necessary to change the values on which it is based and change the awareness of the system as a whole. The hardest and certainly most important thing is to change the social mentality and institutional behaviour of political authorities.

\section{References}

[1] Sarajlic, E.: Political elite in Bosnia and Herzegovina and the EU: Political elite in the theoretical perspective, the Institute for Social Research, Faculty of Political Science, Sarajevo, 2009

[2] Arandarenko, M.: The Political Economy of unemployment, 2012, www.poslodavci-apss.org

[3] Draskovic, V., Draskovic, M.: The necessity for institutional pluralism for sustainable economic development: Institutional changes as a determinant of economic development of Serbia, Faculty of Economics, Kragujevac, 2012

[4] Robert, A.: Great scandals in history: Loove system, Kosmos, Geca Kon ad, Belgrade, 1938

[5] Bahro, R.: Alternative - critique of real socialism, Globus, Zagreb, 1977

[6] Galbraith J. K., Changes in modern developed capitalism: The new Industrial State, IC Communist, Belgrade, 1973

[7] Lekovic, V.: Why the economy of the Republic of Serbia needs a developmental State: Institutional changes as a determinant of economic development of Serbia, Faculty of Economics, Kragujevac, 2013

[8] Drašković, V.: Importance of institutionalization and its limitations in period of post-socialist transition, Economic Thought 1-2, Association of Economists of Serbia, Belgrade, 2003

[9] Stiglitc, DZ. E.: Contradictions of globalization, SBM-x, Belgrade, 2004 